\title{
Sciendo
}

Administration, vol. 67, no. 1 (2019), pp. 59-70

doi: 10.2478/admin-2019-0008

\section{European Union, 2018}

\author{
Margaret Mary Malone \\ Institute of Public Administration, Ireland
}

\section{Institutional developments}

On 1 January Bulgaria assumed the six-month presidency of the Council with Austria and Estonia in a supporting role. It was the first time Bulgaria had held the presidency and the occasion marked a decade since it joined the EU in 2007. The motto of the Bulgarian presidency was 'United we stand strong'. Its three priorities were security, solidarity and stability.

On 1 July Austria took over the presidency. The priorities of the Austrian presidency were increasing security at the EU's external borders, fighting irregular (that is, illegal) immigration, securing a more prosperous and competitive Europe through digitalisation, as well as enhancing cooperation with neighbouring countries, particularly the Western Balkans and South-Eastern Europe with a view to promoting stability in the region.

Jean-Claude Juncker, Commission President, paid tribute to Peter Sutherland, who died in January. Juncker described him as 'a true European' and one of the founding fathers of the Erasmus programme, said to be Sutherland's own proudest policy achievement. Sutherland was also instrumental in shaping the internal market and EU competition policy as we know it today. He had a long and distinguished international career, serving as European Commissioner for Competition from 1985 to 1989 in the first Jacques Delors Commission. He later became Director General of the General Agreement on Tariffs and Trade, becoming Director General of its 
successor organisation, the World Trade Organisation (WTO). He was also UN Special Representative for International Migration from 2006 to 2017.

On 1 March Martin Selmayr took over as the Secretary General of the European Commission. On 21 February, at a weekly meeting of the College of Commissioners, Selmayr had been first promoted from being Juncker's chef de cabinet to Deputy Secretary General of the Commission. At the same meeting, the retirement of Alexander Italianer, the incumbent secretary general was announced unexpectedly whereupon Selmayr duly became his successor. The College of Commissioners confirmed the appointments in a matter of minutes. Neither position was advertised. While Selmayr's competence and qualifications for the Commission's top post were never in question - he is widely respected as a brilliant lawyer and a committed European - the rapidity of the appointment surprised and dismayed some members of the European Parliament, which then asked the EU Ombudsman, Emily O'Reilly, to investigate the matter. O'Reilly began her investigation in May and reported in September. Her investigation did not concern itself with an assessment of Selmayr himself. Instead, O'Reilly criticised the College of Commissioners as a whole for the manner in which Selmayr was elevated to the post of secretary general: she found that no commissioner seriously questioned the way in which Selmayr was promoted. She went on to recommend that, in future, the position be advertised in advance.

On 22 January Paulo Centeno was formally appointed President of the Eurogroup, the committee of economic and financial affairs ministers of the eurozone.

With the UK due to leave the EU formally on 29 March 2019 and European elections to follow in May 2019, the question of what to do with the 73 UK seats in the European Parliament arose. In its June plenary session, the European Parliament voted to adopt a report which would reduce the number of seats from 751 to $705: 46$ seats will be held in reserve for future enlargement while 27 seats will be redistributed to member states that are currently slightly underrepresented. In short, no member state will lose seats as a result of Brexit. Indeed, some member states, including Ireland, will gain. The two seats in Ireland will go to the Dublin and Ireland South constituencies.

The distribution of seats for the period 2019 to 2024 is shown in Table 1. 
Table 1: European elections in 2019 - seats per member state (changes in italics)

\begin{tabular}{lllclc}
\hline Belgium & 21 & France & $79(+5)$ & The Netherlands & $29(+3)$ \\
Bulgaria & 17 & Croatia & $12(+1)$ & Austria & $19(+1)$ \\
Czech & & Italy & $76(+3)$ & Poland & $52(+1)$ \\
Republic & 21 & & & & \\
Denmark & $14(+1)$ & Cyprus & 6 & Portugal & 21 \\
Germany & 96 & Latvia & 8 & Romania & $33(+1)$ \\
Estonia & $7(+1)$ & Lithuania & 11 & Slovenia & 8 \\
Ireland & $13(+2)$ & Luxembourg & 6 & Slovakia & $14(+1)$ \\
Greece & 21 & Hungary & 21 & Finland & $14(+1)$ \\
Spain & $59(+5)$ & Malta & 6 & Sweden & $21(+1)$ \\
\hline
\end{tabular}

\section{GDPR comes into effect}

On 25 May the General Data Protection Regulation (EU) 2016/679 (GDPR) came into effect. This new law regulates the way in which businesses and organisations, public and private, process and manage personal data, requiring them to protect the privacy of residents of EU countries. The aim is to put EU citizens in control of their own data, enhancing individuals' privacy rights in the digital age. In practical terms, it means that EU citizens now have the right to access, modify, correct and remove their personal information collected on databases at any time. Companies will have to ask explicitly for approval and consent in order to use personal data. Settings on online apps and services will have to be privacy-friendly by default. To comply with GDPR, companies must carry out a basic audit on what information they hold, how it is used, and who outside the company has access to it.

Companies now have to disclose data breaches to authorities within three days, or face large fines. Under this legislation Helen Dixon, Ireland's Data Protection Commissioner, has a new authority to investigate and fine companies (including 'Big Tech' companies such as Facebook, Apple, Google, Amazon and Microsoft) if they are found to be in breach of the new rules. Data brokers who amass and sell large data sets of personal information for direct marketing purposes are most exposed potentially to enforcement actions and law suits.

\section{Immigration talks in the European Council}

On 28 June, in a crucial meeting of the European Council, national leaders agreed on how to deal with immigration after all-night talks to 
overcome Italian demands for more help. Giuseppe Conte, the prime minister of Italy's populist and anti-immigration coalition government, had threatened to veto joint statements for the entire agenda until his demands were met. Italy had in late June refused to allow several migrant rescue boats dock in its ports, demanding that the responsibility for people arriving across the Mediterranean be shared. National leaders agreed, inter alia, to set up joint asylum-processing sites and restrict immigrants' movements within the EU. Relocation and resettlement will be on a voluntary basis, not using a mandatory national system. The external border of the EU will be tightened. Finally, it was agreed to increase financing for Turkey and North African states to prevent further migration to Europe, thus taking more action upstream in the countries of origin. A 'partnership with Africa' would see an increase in development funding and a new framework to enable increased private investment from both Africans and Europeans.

In general, flows into the EU of immigrants fleeing Syria and other conflict regions have declined sharply since their peak in 2015 and 2016.

\section{Grexit means Grexit - Greece exits third bailout programme}

Following eight years of strict austerity, Greece successfully exited its third bailout programme on 20 August. This was achieved without the need for a precautionary line of credit. This third bailout was funded by the European Commission and the European Central Bank (ECB). The International Monetary Fund (IMF) was not involved as it may not lend to an insolvent state.

Greece now enters a period of 'enhanced surveillance' by the European Commission, the IMF, the ECB and the European Stability Mechanism. This will include quarterly reports to monitor that the country stays on track with its agreed economic reforms. At 178 per cent of GDP, Greece's sovereign debt is the highest in Europe.

\section{Italy's proposed budget for 2019 - the European Commission reacts}

In March there was a general election in Italy. Two populist political parties on a Eurosceptic platform - the anti-establishment Five Star Movement, a web-based protest party led by Luigi di Maio, and the hard-right, anti-immigration Lega, led by Matteo Salvini - won more 
than half the vote as Italians voiced frustration about immigration, security and social issues, including high youth unemployment. The two parties combined to take office, constituting the first all-populist coalition government in Western Europe, igniting fears that Italy, a founding member state of the EU, could pull out of the euro and strengthen ties with Russia. Giuseppe Conte became Prime Minister while Luigi Di Maio became the Economics Minister, with Matteo Salvini being the Deputy Prime Minister and Minister for Internal Affairs.

In October the populist government unveiled a draft budget for 2019 which, if implemented, would have entailed a budget deficit of 2.4 per cent, exceeding a previously agreed budgetary target of 1.8 per cent of GDP. This target was intended to help bring Italy's public debt, currently running at 132 per cent of GDP, under control. The Five Star Movement and Lega believed they had an electoral mandate to 'abolish poverty' via two flagship measures in particular, namely the introduction of a universal basic income and far-reaching pension reforms. Predictably, the European Commission rejected the draft budget and asked Italy's populist coalition government to resubmit its proposals. Initially, the Five Star Movement and Lega held fast to their electoral promises. The Commission, as Guardian of the Treaties, duly warned the Italian government on 21 November that the 'excessive deficit procedure', a disciplinary process, could be triggered that could, in theory, lead to punitive fines being imposed on Italy. Meanwhile Moody's, a credit ratings company, downgraded Italy's creditworthiness status from Baa2 to Baa3, its lowest investment grade.

In early December a crisis appeared to be averted when Giuseppe Conte agreed that Italy would review the draft budget to include a more limited universal basic income and a more moderate attempt to overhaul the pension system. The budget deficit therefore is likely to be 2.04 per cent of GDP.

\section{Multi-annual Financial Framework, 2021-2027}

In May, following a series of public consultations, the Commission published its proposals on the new Multi-annual Financial Framework (MFF) for the period 2021 to 2027. The main proposals included:

- a 4 per cent cut in direct payments in the EU's Common Agricultural Policy (CAP); 
- a 5 per cent cut in CAP spending;

- a mandatory subsidy cap of $€ 60,000$ per farm in order to redistribute subsidies away from the biggest farms;

- a 7 per cent cut in Cohesion Funding:

- the research programme 'Horizon Europe' may receive 40-50 per cent more funding;

- the budget for the student programme Erasmus and other exchange programmes to be doubled, as well as $€ 700$ million for free Interrail passes for young people;

- regarding migration policy, more financial rewards to member states which take in more migrants;

- on border security, the existing border and coast guard force to be strengthened with a new standing corps of 10,000 border guards;

- on the environment, a 25 per cent increase on activities related to climate protection.

One innovative and controversial proposal was to introduce conditionality between EU funding and the rule of law. New mechanisms could allow the EU to suspend, reduce or restrict access to funding to member states deemed to be at risk of undermining this core value of the EU. The EU will spend nearly $€ 20$ billion on defence over the 2021-7 period to boost its resilience to the perceived threat from Russia, including $€ 4.1$ billion on defence research (e.g. robotics and drones) and $€ 6.8$ billion on assets such as tanks and helicopters. Also, the Commission sought to establish a link between cohesion and migration policies. Under its proposals, states will have to spend 25 per cent of European Social Fund Plus resources on social inclusion, including migrants.

In what may emerge as a key battleground, net contributor countries signalled their preference for a shift from agriculture and regional development to future challenges, e.g. defense, immigration, security and climate change.

Negotiations between the institutions is due to continue throughout 2019.

\section{EU-Asia relations strengthened}

On 17 July the Japan-EU Economic Partnership Agreement (JEEPA) was signed, creating the largest free trade area in the world with 600 million people. JEEPA will remove almost $€ 1$ billion worth of duties paid by EU member states every year to export to Japan. The Agreement was widely seen as a riposte to the protectionist approach 
of the Trump administration and President Trump's attacks on free trade and the rules-based international order in general. Political cooperation was also enhanced with the signing of a Strategic Partnership Agreement in which both the EU and Japan commit to working together to counter global challenges such as cybercrime, disaster management, energy security, climate change and aging societies. Upon becoming US President, Donald Trump pulled the US out of the Trans-Atlantic Trade and Investment Pact (T-TIP) with the EU, as well as the Trans-Pacific Partnership, fulfilling electoral promises.

In a similar vein, on 16 July the EU and China agreed plans to enhance market access and investment.

\section{President Juncker goes to Washington}

On 25 July a potential trade war between the EU and the US was averted when Jean-Claude Juncker, representing the EU28, together with US President Donald Trump gave a surprise news conference in the Rose Garden of the White House announcing a new trade deal. The deal is mutually beneficial. It includes, for example, a substantial increase in EU imports of US soybeans. Soybean farmers in the US Midwest had been badly hit by retaliatory measures imposed by China in response to US tariffs. The EU will also increase imports of liquefied natural gas to help EU member states diversify their energy supplies. Both pledged to resume trade talks to work together towards zero tariffs, zero non-tariff barriers and zero subsidies on non-auto industrial goods, as well as reducing barriers to facilitate an increase in trade in services, chemicals, pharmaceuticals and medical products. The aim is to open markets for farmers and workers, increase investment and lead to greater prosperity in both the EU and the US. This deal could result in some or all chapters of T-TIP being revisited. Also, both agreed to work together to reform the WTO to address unfair trading practices, including intellectual property theft, forced technology transfer, industrial subsidies, distortions created by stateowned enterprises, and overcapacity.

Optimists greeted the deal enthusiastically, hoping that it heralded a new positive phase in the EU-US relationship. As part of the deal, the US will reassess recently imposed US tariffs on EU aluminium and steel. No new US tariffs on EU cars will be introduced so long as talks continue. EU tariffs on motorboats, orange juice and bourbon will be dropped when US tariffs on EU steel and aluminium are dropped. 


\section{Brexit}

Throughout the year, a beleaguered Theresa May struggled to unite her fractured cabinet, party and Parliament on the Brexit talks. May's 'Chequers' plan was based on a common rulebook on industrial goods and agriculture but not services. It was ostensibly agreed in July in a short-lived display of cabinet unity at the prime minister's country retreat. Jacob Rees-Mogg, a hard Brexit proponent and backbencher, urged his Westminster colleagues to force Theresa May 'to chuck Chequers!' Subsequently, the plan prompted a spate of ministerial resignations, including David Davis and Boris Johnson, as well as the latter's younger brother, Jo. The Chequers plan was in any case rejected by Michel Barnier as an unacceptable exercise in 'cherrypicking', reflecting the resolve of the EU27 to preserve the integrity of the single European market. The talks continued.

On 25 November, at a special meeting of the European Council, the EU27 Heads of State or Government endorsed unanimously the 'Withdrawal Agreement' (WA) reached by the negotiating team of the EU27, headed by Michel Barnier, and the negotiating team of the UK, headed effectively by Theresa May. This treaty, which becomes legally binding upon ratification by the UK parliament and the European Parliament, is due to enter into force on 30 March 2019, facilitating an orderly UK exit from the EU. The European Council also approved the non-binding political declaration on future EU-UK relations which will form the basis of talks on the future trade relationship.

The 585-page WA comprises 185 articles, 3 protocols (on Gibraltar, the UK base areas in Cyprus, and Ireland/Northern Ireland), as well as several annexes. The WA covers three priority issues:

i. Citizens' rights: EU27 citizens in the UK and UK citizens in the EU27 will continue to be able to live and work after 30 March 2019 as before.

ii. Financial settlement: The UK will meet the financial commitments already entered into while the UK was a member state. This amounts to some $£ 39$ billion.

iii. Avoiding a border between Northern Ireland and the Republic of Ireland: From the outset, the most difficult element of the WA was how to avoid the return of a hard border in Ireland in all circumstances. The issue was how to reconcile frictionless trade between both parts of the island of Ireland with Britain's departure from the EU's single market and customs union. The 
'backstop' arrangement eventually agreed means that the UK as a whole will remain in a single EU-UK customs territory 'unless or until' an alternative trading relationship is agreed that avoids a border, thus rendering the backstop unnecessary. In other words, the backstop is effectively an insurance policy or a safety net - it is not intended to be used. Under the provisions of the WA, the UK may not exit the customs union arrangement unilaterally. Opponents of the deal argued that the UK could conceivably remain in lockstep with EU rules indefinitely without having any say in the making of those rules.

The WA provides for a transition period to facilitate negotiations to conclude an agreement on the new EU27-UK trade relationship. This transition period will begin on 30 March 2019 and end on 31 December 2020. This coincides with the end of the current MFF. It may be extended once only, for a limited but unspecified period of time, if the UK and the EU27 decide jointly to exercise this option by 1 July 2020. Importantly, the transition period applies only if the WA comes into effect, which it can only do if it is approved and ratified by the British Parliament. In short: no WA, no transition. In this case, Britain would leave the EU without a deal, and a cliff-edge or hard Brexit - a disorderly exit causing chaos and economic turmoil - would ensue.

The non-binding political declaration sets out the framework for the future trading relationship between the EU27 and the UK. It envisages an 'ambitious, broad, deep and flexible partnership across trade and economic cooperation, law enforcement and criminal justice, foreign policy, security and defence and wider areas of cooperation'. The declaration states explicitly that the future relationship 'cannot amount to the rights of obligations of membership'. As Michel Barnier once put it, the UK had decided to leave the EU, so it must accept the consequences.

Theresa May's greatest challenge lay ahead, with the House of Commons due to debate and finally vote on her deal on 11 December. In the event, May delayed the vote to January 2019 given the very real risk of a significant defeat. The WA, a compromise deal, succeeded only in uniting the various factions arraigned against the prime minister, both amongst her parliamentary colleagues as well as parliamentary opposition parties from the Labour Party to the Liberal Democrats to the Scottish Nationalist Party to the Democratic Unionist Party (DUP). The Conservative Party has had a 'confidence and supply' arrangement with the DUP since June 2017. 
If the House of Commons passes the WA in early 2019, the European Parliament would then vote to pass the WA by means of a simple majority. The process then moves to the European Council, which would approve the WA, needing a minimum of twenty member states representing at least 65 per cent of the EU population. Both votes are expected to be carried without difficulty as the unity of the EU27 on Brexit has remained strikingly robust from the outset of the talks.

If the WA is not passed by the House of Commons, a range of options open up. The UK could:

- Leave without a deal: It is widely feared that this disorderly or cliffedge exit would lead to an indefinite period of economic turmoil or chaos. The vast majority of MPs are keen to avoid this outcome.

- Renegotiate the deal: Both Theresa May and the European Commission have been adamant that this deal is the best deal and, indeed, the only deal available. For Theresa May, therefore, it is a case of her deal, no deal or no Brexit.

- General election: In theory the next general election is due in May 2022 under the terms of the Fixed-Term Parliaments Act, 2011. An earlier election could take place if a supermajority of two-thirds of MPs emerges in favour of it.

- A new referendum: This outcome is seen by some MPs as a logical course of action in the event of the House of Commons failing to pass the deal. A 'people's vote', as it has become known, could enable the electorate to indicate what kind of Brexit they want or even choose to remain in the EU after all. Others took the view that a new referendum would entrench public division on an already toxic issue in British politics and prolong uncertainty in the shortto medium-term.

- Revoke or extend Article 50 of the Treaty on European Union (TEU): Speculation built throughout the year that, should the House of Commons fail to pass the WA, it may choose to instruct the government to either revoke Article 50 or extend it for a period. The former is easier than the latter as the UK can decide unilaterally to revoke Article 50 and thus park Brexit. Extension requires the unanimous support of the EU27.

On 10 December the European Court of Justice in Luxembourg ruled that Britain could revoke unilaterally the notification of its intention to withdraw from the EU under Article 50 if it chose. There is nothing in Article 50 to prevent this. The ruling surprised few and added to 
mounting pressure for a new referendum. In reality the issue is less judicial in nature than it is political. Theresa May has repeatedly ruled out a new referendum.

Thus, as the year approached its close, the UK effectively entered unchartered waters. Under EU rules, the UK is due to leave the bloc on 29 March 2019, with or without a deal. May's opponents accused her of trying to 'run down the clock', leaving the House of Commons no choice but to approve the WA if they wish to avoid a cliff-edge, nodeal exit. It is unclear if there is a parliamentary majority in favour of any form of Brexit, so the possibility of a hard Brexit or, indeed, no Brexit or anything in-between cannot be excluded.

\section{'Republic of North Macedonia'}

In June Greece and the former Yugoslav Republic of Macedonia signed a historic agreement to rename the latter the 'Republic of North Macedonia'. This accord ended a row that has poisoned relations between the neighbours since 1991. Importantly, the end of this name dispute paves the way in principle for accession talks for the North Macedonians not only with the EU but also with NATO. 'Macedonia' is the name of a province in Greece. For this reason, previous Greek governments objected to another country appropriating the name and the territorial claim this implied.

\section{MEPs launch Article 7 TEU proceedings against Hungary}

In September MEPs, having the two-thirds majority required, triggered Article 7 TEU proceedings against Hungary for a serious and persistent breach of the EU's fundamental values, including the rule of law. This procedure, the so-called 'nuclear option', could ultimately lead to Hungary being stripped of its voting rights in the Council of the EU. The next step is a vote in the European Council, where a four-fifths majority is required.

Poland is facing a similar Article 7 legal action. In December 2017 the European Commission initiated Article 7 proceedings against Poland in respect of its Law and Justice (PiS) government's controversial constitutional reforms which, inter alia, forced the retirement of judges in the Supreme Court. In November of this year the PiS government rushed through amending legislation to reverse some of its measures. As a result, Supreme Court judges who had been forced to retire may return to work if they wish. 


\section{The beginning of the end of the Merkel era}

On 29 October, in the wake of a poor showing in a number of regional elections, Angela Merkel announced she would not stand for reelection as leader of the Christian Democratic Union (CDU) party in December 2018 and would not seek a new political mandate as Chancellor in 2021 when the next federal elections take place. On 7 December the CDU party chose Annegret Kramp-Karrenbauer, or AKK as she is more popularly known, as its new leader. Dubbed 'miniMerkel' by some, AKK was widely seen as the continuity candidate. A close political ally, AKK is expected to respect Merkel's preference to remain on as Chancellor until 2021. This would allow a gradual transfer of power to her successor.

Born in Hamburg, Angela Merkel grew up in the communist German Democratic Republic, or East Germany, when her father, a pastor, moved the family there. Trained as a physicist, she entered politics after the fall of the Berlin Wall in November 1989. Joining the CDU, she became the protégée of Helmut Kohl, who was Chancellor of West Germany from 1982 to 1990 and Chancellor of a reunited Germany from 1990 to 1998 . Merkel became CDU party chief in the year 2000 and German Chancellor for the first time in 2005, the first female and the first East German to hold this post. She went on to become Chancellor for four consecutive terms. 